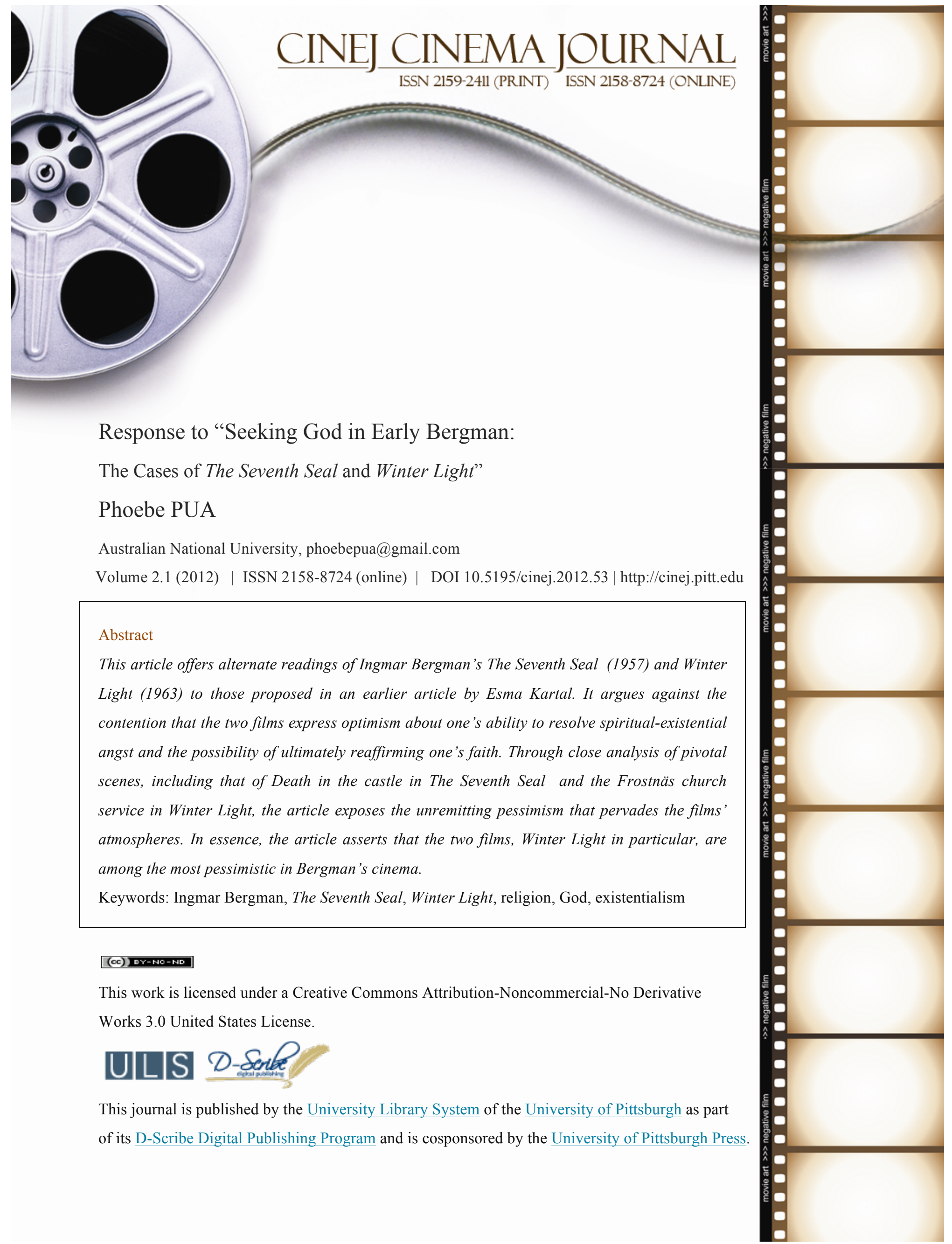




\section{Response to "Seeking God in Early Bergman: The Cases of The Seventh Seal and Winter Light"}

With her article, Esma Kartal contributes to the increasing body of scholarship addressing the religious motifs in Ingmar Bergman's cinema during the late 1950s and early $1960 \mathrm{~s}^{1}$. It has been six decades but interest in the director and his cinema remains unabated. Despite this, one would be hard-pressed to find unanimous interpretations of Bergman's films. This is hardly surprising since films like Såsom i en spegel/Through a Glass Darkly (1961) and Nattvardsgästerna/Winter Light (1963) conclude with famously open resolutions and have left scholars agreeing to disagree.

Kartal discusses the religious angst expressed in Det sjunde inseglet/The Seventh Seal (1957) and Winter Light. She argues that despite Bergman's reputation as the "Solemn Swede," in these films "one witnesses an optimistic approach in the end" as "there is still hope ... [for] personal salvation" (80). She holds that at the end of the films both Antonius and Tomas have battled their religious doubt and have emerged victorious, in a spiritual sense. These victories, Kartal contends, grant the films an optimism that is so rarely seen in Bergman' mature cinema and thus challenge the perception that his is a cinema of gloom.

Though I agree with Kartal's interpretation of The Seventh Seal as concluding with an expression of optimism and hope, to my mind, this optimism is located more in an existential than a religious or spiritual dimension. I do not perceive Antonius as achieving spiritual triumph-whether in the sense of reconciling with his silent God or arriving at satisfactory answers about the existence (or non-existence) of this God. Through his "one significant act", Antonius does achieve "personal salvation," and as Kartal argues, he has "found an earthly equivalent [of God in the form of] the capacity for love and human kindness" $(83,84)^{2}$. However, this earthly salvation neither qualifies as a spiritual triumph nor relieves Antonius of his desperate yearning for knowledge about the metaphysical. The inadequacy of his significant act becomes apparent when Antonius encounters Death at his castle and an ultimate despair breaks through his façade. It is this scene which compels me to rethink an easy categorization of The Seventh Seal as a film that expresses optimism about the human endeavor to resolve spiritual agony. 
Undeniably, Antonius's selfless sacrifice, which, however temporarily, saves Jof's family from Death's grasp, is itself enough to lift the solemn atmosphere of The Seventh Seal. Furthermore, the final scene shows the family, having weathered a rough storm, enjoying the dawn of a new day. That they represent the Holy familyJof/Joseph, Mia/Mary, and Mikael/infant Jesus_-only heightens the film's promise of a new beginning, not unlike the promise of salvation and renewal experienced by Noah and his family in the Genesis flood narrative (Genesis 6-9). In the middle of film, one is also allowed respite from the chaos in the form of communal bliss. The oftmentioned scene where the group enjoys a secularized communion of fresh milk and wild strawberries offers one of the clearest depictions of earthly bliss in Bergman's cinema ${ }^{3}$. The optimism that Kartal perceives in The Seventh Seal is unquestionably present.

Yet, while this is true, one must question how far these instances of love and hope enable one to move past the film's general tone of apocalypse, death, and damnation. Even in scenes of humanity and peace, death is never far. For instance, in the aforementioned hillside communion, Skat's death mask hangs on a branch behind them while the group enjoys each other's company. The mask is an ominous reminder of Antonius's pact with Death and the latter's apparent omnipresence. Though by the end of the film Jof and his family have managed to escape an encounter with Death, one can expect that they will soon bear witness once more to his far-reaching embrace. With this in mind, easy categorization of The Seventh Seal as either an optimistic or pessimistic vision of the times proves difficult. The films that precede it, such as Sommarnattens leende/Smiles of a Summer Night (1955), are notably delightful amorous comedies. In comparison, The Seventh Seal does appear to be uncharacteristically dark. In this way, the film, along with others from the $1950 \mathrm{~s}$, belongs to a period in Bergman's cinema that is characterized by what Jesse Kalin calls "gloomy optimism" (xiv). These films acknowledge the misery of life, propose that life itself is hell on earth, but never surrender under the gravity of such knowledge nor renounce the right to live. Kalin describes the central films of the 1950s in this way:

A more comprehensive and archetypal picture of life that celebrates the cycles and rhythms of coming to be and perishing; the flourishing and passing of love; youth and age; the different times, seasons, and smiles of life; and above all the discovery of a second chance. Each individual story is part of a great narrative scheme, and our grief and suffering a moment in a larger grand dance of life. (xiv-Xv) 
The cyclical nature of existence that Kalin alludes to is expressed in the closing sequences. Death's conquest of Antonius and his group of travelers ends in a dissolve to a shot of Jof's family waking up to the clear skies of a new morning. Through death comes new life; this is the established order, the wheel of life ${ }^{4}$. When Jof witnesses the danse macabre, he does not perceive it as a vision of pure horror or hope, but a mixture of both. It prompts the same reverence in Jof as does his previous vision of the Virgin Mary and the infant Jesus, but at Mia's teasing he is able to shrug it off and continue with his life. It simultaneously reminds one that death is never far and that one has to forge on in spite of life's gloomy realities ${ }^{5}$. This is the existential victory in The Seventh Seal and is perceptibly the only dimension of optimism in the film.

Antonius's endeavor to resolve his spiritual agony does not end on a hopeful note — most of all because his quest to find his silent God is proven to be humiliatingly futile. The suggestion that an earthly equivalent of God can be found through brotherly love is admirable but also naïve. Admittedly, the hillside communion inspires Antonius; his transition from a doubting Knight to confidence personified is evident. One could compare, for example, two encounters between Antonius and Death-first, in the confessional early on in the film, and second, when they meet again after the hillside communion.

In the first, what begins as a moody lament erupts into an angst-ridden confrontation with the priest (later revealed to be Death) from whom Antonius demands assurance of the existence of God. From a desperate plea for answers, the exchange culminates in an accusation that God is aloof and intentionally unknowable:

KNIGHT. I want knowledge.

DEATH. You want guarantees?

KNIGHT. Call it whatever you like. Is it so cruelly inconceivable to grasp God with the senses? Why should He hide himself in a mist of half-spoken promises and unseen miracles?

DEATH does not answer.

KNIGHT. How can we have faith in those who believe when we can't have faith in ourselves? What is going to happen to those of us who want to believe but aren't able to? And what is to become of those who neither want to nor are capable of believing?

The KNIGHT stops and waits for a reply, but no one speaks or answers him. There is complete silence.

KNIGHT. Why can’t I kill God within me? Why does He live on in this painful and humiliating way even though I curse Him and want to tear Him out of my heart? Why 
in spite of everything, is He a baffling reality that I can't shake off? (28, original italics)

His barrage of questions bespeaks his frustration at God's silence towards him and humankind at large. The questions are almost rhetorical, he does not wait for Death to provide him with answers; instead he incrementally poses one question after the other. The rhythm of this exchange contrasts dramatically with that of a later encounter following the hillside communion.

After leaving the group to enjoy their feast and Jof's music, Antonius meets Death once again to continue their game:

DEATH. Why do you look so satisfied?

KNIGHT. That's my secret.

DEATH. Of course. Now I take your knight.

KNIGHT. You did the right thing.

DEATH. Have you tricked me?

KNIGHT. Of course. You fell right in the trap. Check!

DEATH. What are you laughing at?

KNIGHT. Don't worry about my laughter; save your king instead.

DEATH. You're rather arrogant.

KNIGHT. Our game amuses me.

DEATH. It's your move. Hurry up. I'm a little pressed for time.

KNIGHT. I understand that you've a lot to do, but you can't get out of our game. It takes time. (55)

Antonius appears to have lost his desperation and urgency. While the previous exchange resembles a monologue, here Antonius engages Death in banter, taking on a playful and arrogant tone. The tables have turned, it is now Death who is "pressed for time" and Antonius is deliberately evasive. The suggestion is that the hillside communion has given Antonius the answers he so desperately seeks. One assumes that he is no longer 
apprehensive about death or preoccupied with questions of God and the possible afterlife. He tells the group that the memory of their communion "will be an adequate sign [and] it will be enough for [him]" (55). The significance of his memory is proven when he sacrifices his life to ensure the safety of Jof's family. It is plausible that for enlightened Antonius, as Kartal argues, this earthly equivalent of God "is more than enough to find God" (84).

Whether or not that is true (are earthly equivalents of God really enough to find God?), the message in itself is one of optimism and hope. However, this optimism ultimately proves inadequate. Antonius's satisfaction with his one significant act is summarily shattered upon meeting Death at the castle. His inspired confidence gives way to another bout of desperation and paralyzing doubt. As the group — now joined by Antonius's wife, Karin—has their last meal together, the sacred quality of their communion is now replaced by somberness. Karin reads the biblical passage of the opening of The Seventh Seal (Revelations 8:1-11) echoing the intertitles that open The Seventh Seal. As Karin reads, the group "listen tensely to the stillness," there is no question they are anticipating Death's arrival (Bergman, The Seventh Seal, 80). When Death does arrive, of all those present, it is only Antonius who cowers in fear. The film's enlightened hero "hides his face in his hands" as the rest introduce themselves stoically (81). The confidence that his existential epiphany had previously inspired in him has been dispelled by the religious doubts he failed to exorcise. While the film had previously led its audience to believe that brotherly love is sufficient as the earthly equivalent (or proof of the existence) of God, it now exposes its inadequacy in placating the tortured religious individual. Antonius is reduced to a whimpering shadow of his former self; the redemptive power of existential epiphanies is renounced and once more, Antonius begs God to emerge from His silence. In essence, Antonius's tale is an immensely pessimistic one. What is suggested is that the individual is capable of becoming painfully aware of God's silence, but incapable of compelling God to speak (or manifest in a tangible way), incapable of accepting this silence as proof that God does not exist, but yet also incapable of unquestioningly accepting that God exists. For many, Jöns's approach of indifference to the question of God's existence is the answer and one recognizes the Camusian hero in Jöns. By his own will, Jöns is an active force- to name a few instances, he saves both the girl and Jof from Raval, scars Raval in an act of revenge, and lends the soldiers a hand when the carriage is stuck. His areligious and purely existentialist approach to life allows him to remain defiant in the face of death; he instructs the group to "feel the immense triumph of this last minute when you can still roll your eyes and move your toes" (81). However, though Bergman recognizes the advantages of Jöns's approach, what is implied is that such an approach to life is simply unavailable to Antonius, one who had been indoctrinated by religious beliefs and, at least for some time, thought them to be timeless and true. The distinct biographical aspect seen here is echoed throughout the many films Bergman produced, especially in the 
early 1960s, where he constantly negotiates with his ideas of God, moving back and forth between a confirmation of His existence and a rejection of it $^{6}$.

When examined as a whole, the structure of The Seventh Seal (concluding as it does with the scene of Jof's family enjoying a new day) supports Kalin's interpretation of it as exhibiting a gloomy optimism. But with regard to the quest to resolve religious doubt and subsequently achieve personal salvation, the film culminates in pessimistic resignation regarding the individual's inability to confirm (or reject) God's existence and the futility of his attempts to do so.

With Winter Light, I depart from Kartal's reading radically. To my mind, it is one of the most pessimistic films in Bergman's cinema. Beyond the obvious metaphors of spiritual emptiness portrayed by the barren, wintry Swedish landscape and the empty church pews, the film's tone is indeed one of impotence and void ${ }^{7}$. While The Seventh Seal and Through a Glass Darkly had only alluded to the great question, "Why must we go on living?" (Berman, A Film Trilogy, 74), Winter Light asks it in a most forthright manner-and not only does it not suggest an answer but it instead seems to suggest that there is none. When Jonas Persson poses this question, Tomas can neither answer it nor hold his gaze.

Yet, despite such gloomy assertions, there is much discussion surrounding the film's ultimate stance on the possibility of resolving religious doubt and reaffirming faith. After all, the contention that Tomas achieves some sort of religious or spiritual epiphany is valid. As Kartal argues:

After his second encounter with Jonas we are left with a close-up of Tomas's face that is brightened by the beams of light coming from the window . . . [quoting Hubert I. Cohen] "this burst of light is the sign of His approval of Tomas's arrival at a truer sense of reality." (1993, 188) At that moment he feels God's silence as the God in him is dead. (83)

This epiphany, a metaphorical illumination emphasized by a literal illumination, is the elusive liberation from God and religious doubt that Tomas, and Antonius of The Seventh Seal, seeks. Antonius failed to achieve this liberation_- “why can't I kill the God within me?” (Bergman, The Seventh Seal, 28)_but the suggestion is that Tomas has. After the bright light streams in illuminating him, he utters emotionlessly, "God, why have you 
abandoned me?" $(87)^{8}$. Here, it appears that Kartal's argument is that at this point, Winter Light is not a film that expresses optimism about reaffirming faith — an argument I agree with. However, Kartal goes on to argue that this death of God that Tomas experiences gives rise to a new image of God- "Tomas has discovered a new way of perceiving God and he begins to form a new idea of faith in his mind" (84) — and through that achieves personal salvation, as can be witnessed in the final scenes where Tomas forges on with the second church service despite his ill health and having no obligation to continue given the lack of attendants. As Kartal notes, Cohen shares her hopeful interpretation of the ending, and he argues, "it [the closing sequences] is infused with . . . a rekindled faith in a redefined God" (193). The article, "Winter Light," by the Ingmar Bergman Foundation expresses a similar sentiment, making reference to Bergman's own description of the ending as depicting "the stirrings of a new faith" (n.pag) ${ }^{9}$. Given Bergman's own declaration, it would seem indisputable that Winter Light offers an ultimately affirmative vision of faith.

However, it must be noted that these interpretations are founded primarily on comments Bergman made during the time he was drafting the screenplay for Winter Light. Vilgot Sjöman recorded the comments in L136: Diary with Ingmar Bergman, along with many conversations where Bergman used Sjöman as a sounding board for his ideas. There is significant merit in studying these conversations; after all, Bergman's cinema is very much about the director himself. Despite the disavowal of auteurism by several factions of film studies, the usefulness of the auteur approach to a cinema like Bergman's is undeniable. That being said, dogged allegiance to Bergman's comments is problematic. It should be noted that the comments in question were made during the time when Bergman was still in the process of writing the screenplay and pinning down the exact tone he wanted the film to exude. Beyond this, the film itself is the intended object of study and must stand on its own; the filmmaker's comments are relevant but cannot be allowed to take precedence over the film.

As can be expected of any film, there are differences between the screenplay and the actual film. In Winter Light, these differences become crucial in their ability to demonstrate the changing attitudes Bergman had toward the subject matter from the time of writing to that of filming. Quite remarkably, it would appear that Bergman began the writing process with renewed hopefulness, as can be seen from his vision to close the film with "the stirrings of a new faith". It is from this comment that many have developed their interpretations about Winter Light's religious optimism. Sjöman notes that Bergman had intended for the film to be broken into three sections, the final one is as follows: 
3. THE FLOWERING OF A NEW BELIEF. "That's the most difficult part to write. I think I've found a solution. Have you heard of 'duplication'? Certain Sundays the pastor has two services to perform: the one in the parish church and then one for a mission congregation. Now there is a practice in the Swedish church which says that no service need to be held when there are three persons in the church. This is what I do: When Gunnar Björnstrand arrives at the mission church the warden comes forward toward him and says: 'Only one person is here for the service.' Nevertheless, the pastor conducts the service. Nothing more is needed to indicate the new feeling which moves inside the pastor." (Cinema Journal 37)

Here, Kartal's argument is supported by Bergman's declaration. However, this comment, dated "10 July 1961," was made when Bergman was still mid-way through the writing process $(36)^{10}$. " Bergman finished ... 4th October 1961" with "On the screenplay, it is stated that Bergman finished it on "August 7, 1961" and the Ingmar Bergman Foundation notes in the article "Winter Light: Film Facts" that filming began on 4th October 1961 (Bergman, A Film Trilogy, 73). His vision of the film was subject to much change throughout the duration of writing and until 2nd October, Bergman's perspective of the concluding sequence was still constantly shifting:

[10 August 1961]

"The end. One never feels the 'flowering of a new belief' in Tomas. He just goes in and does the service..."

"Exactly. He is the pack mule that plods on. Much too weak to be of any use in God's work. God can't instill any strength in him"

$\cdots$

[2 October 1961]

Where is Tomas in the final scene, religiously speaking? Here, says Ingmar:

"The mirror is clean. There stands a newly scoured vessel that can be filled by mercy. By a new image of God." (Sjöman 38, 40 original italics)

During an interview in 1969, Bergman recalls the incident that inspired the final sequence of Winter Light: 
In some way I feel the end of the play was influenced by my father's interventionthat at all costs one must do what is one's duty to to do, particularly in spiritual contexts. Even if it can seem meaningless. (Björkman 174)

In The Magic Lantern written in 1988, regarding the same incident, Bergman wrote:

When the hymn was over, he turned to us and spoke in his calm free voice: "Holy, holy, holy Lord of Hosts, heaven and earth are full of thy glory. Glory be to thee, O Lord most High."

Thus I was given the end of Winter Light and the codification of a rule I was to follow from then on: irrespective of everything, you will hold your communion. (273 original emphasis)

In Images in 1994:

He goes through with his service for no other reason than that Märta Lundberg is present. If one has religious faith, one could say that God has spoken to him. If one does not believe in God, one might prefer to say that Märta Lundberg and Algot Frövik are two people who helped raise a fellow human being who has fallen and is digging his own grave.

At that point it doesn't matter if God is silent or if He is speaking. (271)

Taking all this into consideration, does Tomas become a "pack mule that plods on" or a spiritually re-born pastor speaking in a "calm free voice" ready to be "filled by mercy [and] a new image of God"? How are we to interpret Bergman's contradictory statements? What about his dedication, "Torö, 7 August 1961, S.D.G. [Soli Deo Gloria/Glory to God Alone]," on the completed screenplay? (63) $)^{11}$. Ultimately it is essential that these comments be brought into the study of the film itself. While they are important, statements about the film should be subordinate to the film. My argument is that in looking at Winter Light in itself and in its entirety, the atmosphere of gloom and pessimism becomes apparent and is evident in two dimensions_-man's relationship with God and man's relationship with each other. 
As I argued earlier, there is a significant dissonance in Bergman's treatment of religious doubt and salvation as he moves from writing the screenplay to filming it. The screenplay is earnest and possesses a sense of desperation for meaningful metaphysical and human communication not unlike The Seventh Seal and Through a Glass Darkly. However, the actual film is stripped of the screenplay's sentimentalism; for instance, in the previously mentioned illumination scene, the screenplay notes, "TOMAS. (moaning): God, my God, why have you abandoned me?" (87) In the film, however, Tomas is decidedly emotionless ${ }^{12}$. The illumination scene constitutes a pivotal moment in Winter Light as Tomas is finally able to make sense of God's silence, the very phenomenon which cripples him. As Märta said, “God has never spoken because God doesn't exist. It's as simple as that. ${ }^{13 \text { ” }}$ To emphasize the cruel loneliness of existence in a Godless world, the scene is soundless, diegetically and non-diegetically, as the camera closes in on Tomas's face. The silence is as intentional as it is significant; in the screenplay, Bergman uses the words "silence" and "God's silence" repeatedly in the stage directions and in the film silences are heavily present. Tomas is shrouded in silence right from the moment Jonas leaves him to the moment that he walks out from his chamber to the chapel where Märta is waiting. First, chimes break the silence then Tomas, he coughs and whispers", "I'm free now. Free at last" (87). He is liberated from his doubt as he has killed the God within him. This death of God does not give rise to a new image of God but instead affirms his suspicions: "there isn't any creator, no sustainer of life, no design" (86). By Tomas's own admission, the epiphany destroyed his "fleeting hope that everything [religious truths and promises] wouldn't turn out to be illusions, dreams, and lies" (88).

Despite his new reality, Tomas stands up suddenly and announces that he has to head to Frostnäs for his second service. At first glance, the peculiarity of his actions is incomprehensible. If he no longer believes that God exists, why does he still feel the need to conduct another church service? Later in the film, why does he ask the boy if the latter plans on attending confirmation class? In fact, why does Tomas offer to read from the Bible with Mrs. Persson after relaying news of her husband's suicide? Since he realized that God and the promises He made were merely "illusions, dreams, and lies," surely he must have felt that passages from Bible were equally meaningless. The significance of this scene only becomes apparent upon looking at Winter Light as a whole. The scene enables our understanding of the widely debated final sequence. For Tomas, the experience of religion is routine; it is void of actual meaning and significance. That God is dead to Tomas does not affect his decision to conduct another service in His honor, it is an empty ritual and a blind allegiance to a nonexistent God. The question now is whether Tomas is truly free- - he may be liberated from his doubt but he has yet to be liberated from the habit and comfort 
of meaningless rituals. Traces of Bergman's original intention to close the film in an atmosphere of hope remain present. At the service in Frostnäs, Tomas's face is no longer wrinkled by the solemn and frustrated expression he wears in the opening sequence, the altar's effigy of crucified Christ is now one of Mother Mary cradling the infant Jesus, and the first words of his sermon are religiously affirmative ("Holy, Holy, Holy, Lord God Almighty. The whole earth is full of His glory" (104)). Yet, these images cannot diminish the impression of impotence and emptiness surrounding the sequence. Tomas conducts the service out of routine. When Algot tells him that there is only a congregation of one, Tomas pauses as if to deliberate if he should call it off but eventually goes out to perform the service. He does so not because Algot has led him to personal salvation, but because it is routine to him; it is literally a performance ${ }^{14}$. There is no personal spiritual salvation and even whilst proclaiming the positive declarations of his sermon, Tomas remains emotionless. The idea that "the whole earth is full of His glory" brings no joy to Tomas; to him, the words are not even ironic, they are simply meaningless. While The Seventh Seal is pessimistic about one's ability to conclusively confirm or reject God's existence, Winter Light suggests that even if one is able to reject God's existence, it does not guarantee that the idea of God will be completely exorcised from one's consciousness. By Winter Light's suggestion, the tragedy of existence is that much more intense; the tone of the film is immensely more pessimistic.

While the religious dimension of Winter Light is important, the film also conducts a considerably extensive discussion of human communication. It is important to note that when translated, the original Swedish title Nattvardsgästerna, reads "The Communicants". In addition to the dismal prospects of communicating with God, Winter Light also addresses the human inability to meaningfully communicate with each other (in a non-religious spiritual way) or form meaningful interpersonal relationships - an idea that Bergman develops in his next film, Tystnaden/The Silence (1963). Winter Light's vision of this can be observed through two parallel scenes: the first of which is the opening service where the hymns sung ask God to "hear our prayers, O merciful God," "take my hand in Thine/Lead me, gently lead me;" and the second is Märta imploring Tomas to listen to her pleas, "take me and use me," in her letter $(68,70,82)$. Tomas, along with the congregation, desperately tries to communicate with God in the same way that Märta passionately desires to communicate with Tomas. While one does so through hymns, the other uses a letter, and in both cases the distance and lack of immediacy is apparent. Just as God appears indifferent to their pleas, Tomas treats Märta in a cold and detached manner. The implicit suggestion is that because God is silent toward Tomas, he in turn cannot meaningfully communicate with Märta or reciprocate her affection. It could easily be that Tomas simply does not love Märta, after all, his devotion to his late wife 
proves that he is capable of love. However, Tomas does appear to be incapable of, or at least disinterested in, communicating meaningfully with anyone. When Algot enters Tomas's chamber and inquires about the latter's health, Tomas cuts him off mid-sentence and signals for him to leave. With Jonas, Tomas is concerned only with his own confusion, obliging Jonas to indulge him as he tries to make sense of his sudden realization that life is seemingly and inherently meaningless ${ }^{15}$. His encounter with Mrs. Persson is no different; he remains blind to her needs, offering her the empty consolation of reading from the Bible. Beyond Tomas, the deafening silence of God permeates the setting of Winter Light, affecting each individual. Jonas's depression has caused him to withdraw into silence, even from his wife; Märta is extremely verbose but her lengthy declaration of love cannot fill the void of God's silence in Tomas's consciousness, nor is she aware that what he needs is not her affection but liberation from his agonizing spiritual malaise; Algot's interpretation of Christ's final days appears to offer Tomas spiritual clarity, but fails to have a real influence on him; and the communion, though Märta calls it a "“love-feast"," is void of the joy that The Seventh Seal's earthly communion so plainly possesses and is tragicomically incongruous with the sermon's declaration that God "hast instituted this holy communion to our consolation and bliss" (76, 69).

Perhaps the scene that most reveals Bergman's pessimism about the possibility for meaningful human communication is Märta's "prayer” in the Frostnäs church. Upon hearing the church bells, Märta falls to her knees and utters, "if only we could feel safe and dare show each other tenderness. If only we had some truth to believe in. If only we could believe" $(104)^{16}$. The "prayer" is not an affirmation of her new faith in God, instead it bespeaks of her resignation to the wretched state of being alive and yet being unable to meaningfully communicate with another, unable to find some semblance of truth to place one's faith in, and unable to even have faith itself. The repeated use of "if only" disallows an interpretation of a hopeful ending for Märta since although her desires are intense, they only serve as a reminder of her impotence to fulfill them. By the end of Winter Light, the silence of God has morphed into the silence of man. Attempts at communicating with each other are inadequate; essentially, their speech is a muted speech, as communicative (or uncommunicative) as silence itself. In this way, Winter Light expresses profound pessimism about the state of the human individual. One is shrouded in silence and insularity, within a condition which seems impossible to break out of.

In conclusion, though Bergman had a fervent desire to depict the hopeful beginning of a new faith in Winter Light, the ending is an image of the emptiness of religious faith and ritual; in its entirety, the film doubtlessly stands as 
one of Bergman's most quietly depressing comments on faith. Though evidently, The Seventh Seal and Winter Light are two films essential to any discussion of the concept of God in Bergman's cinema, they also exhibit Bergman's investment in the subject of human relationships. While both films are preoccupied with the silence of God and are pessimistic about man's relationship with God, The Seventh Seal presents a considerably more optimistic picture of interpersonal relationships and communication than Winter Light.

${ }^{1}$ Kartal, Esma. "Seeking God in Early Bergman: The Cases of The Seventh Seal and Winter Light." CINEJ 1.2 (2012): 80-85.

${ }^{2}$ The latter section of the statement is quoted, by Kartal, from John C. Stubbs's “The Seventh Seal " (1975). Stubb's article is included in the bibliography of this article.

${ }^{3}$ In a commentary included in The Criterion Collection's The Seventh Seal, Peter Cowie notes the significance of strawberries in Bergman's cinema, "strawberries mean a great deal to Bergman as they do to all Swedes, they are the perfect symbol of summer and Bergman even named his next film 'Wild Strawberries'. And in Summer Interlude made in 1951, there is a very moving sequence where the two lovers share some strawberries on a remote idyllic island."

${ }^{4}$ The painter whom Jöns meets in the chapel early on in The Seventh Seal is identified to be Albertus Pictor (1440-1509), the famous late medieval Swedish painter. Bergman credits Pictor's painting, "Death playing chess," as having inspired Death and Antonius's game of chess (Cowie Biography 143). Among Pictor's work is "Livshjulet" ("Wheel of Life") which depicts death as an inescapable part of life. The text on the painting reads, "I shall reign, I reign, I have reigned, I am powerless".

${ }^{5}$ The idea that the individual must forge on and go on living despite the gloomy realities of life holds true in The Seventh Seal but in Winter Light, Bergman confronts it to greatly depressing results. I discuss this in the second half of the article.

${ }^{6}$ When inquiring about the sudden cessation of religious exploration in the films after The Silence, Jonas Sima asked, "was it after The Silence [that] you became an agnostic?" By Sima's own definition, an "agnostic" was "someone who, after struggling with a group of problems, just drops them. Since he has found no answer to them". Bergman answered, "Or one might say the problem dissolves. Anyway, the crux of the matter is - the problem doesn't exist any more. Nothing, absolutely nothing at all has emerged out of all these ideas of faith and skepticism" (original emphasis). Not only does The Seventh Seal, and later Winter Light, suggest that the quest to move past religious doubt is futile, Bergman himself concluded that his own process of doing so (working through his doubt via his films) was similarly futile. See Björkman 195.

${ }^{7}$ The cinematography set out to create a dreary atmosphere. Bergman noted that "not one shot was taken in direct sunlight. We filmed only when it was overcast or foggy". The film's tone was to be of "a Swedish man in the midst of a Swedish reality experiencing a dismal aspect of the Swedish climate" (Images 264).

${ }^{8}$ In the screenplay, Tomas is not emotionless. Instead it reads, “TOMAS (moaning): God, my God, why have you abandoned me?” (87) The difference in the manner in which Tomas is to deliver the line is pivotal, it cues the audience in understanding if this revelation saddens or relieves Tomas. Since Gunnar Björnstrand delivers the line emotionlessly (as he remains throughout the film), the scene becomes more difficult to interpret. The difference in the screenplay and the film is important and will be discussed further.

${ }^{9}$ Alternate translations read, "flowering of a new belief" (Sjöman Cinema Journal 36) and "A new faith shows signs of life" (Sjöman Ingmar Bergman Interviews 29).

${ }^{10}$ Dated "20 July 1961" in a reprint of the same article in Ingmar Bergman Interviews (29). 
${ }^{11}$ S.D.G (Soli Deo Gloria) translates from Latin to "Glory to God Alone".

${ }^{12}$ See footnote 7.

${ }^{13}$ To my mind, the dialogue from the screenplay is more poignant. Märta recognizes the cruelty of God's silence, and tells Tomas, "God hasn't ever spoken, because he doesn't exist. It's all so unusually, horribly simple” (78 my emphasis).

${ }^{14}$ If one wishes to take into account Bergman's comments—when Allan Edwall (who plays Algot) asks "does Tomas become in some way converted through Algot Frövik?” Bergman replies, “Yes. No. Not so much.” See Sjöman 39.

${ }^{15}$ The screenplay seems more invested in human communication than the film. Tomas tells Jonas before the latter leaves: "You must live, Jonas. Summer's on the way. After all the darkness won't last forever. You've got your strawberry beds, haven't you, and your flowering jasmine? What perfume! Long hot days. It's the earthly paradise, Jonas. It's something to live for! ... We'll see a lot of each other, you and I. We'll become good friends, and talk to each other about this dark day. We've given gifts to each other, haven't we? You've given me your fear and I've given you a god I've killed" (86). The film's Tomas is blind to Jonas's twisting anxieties and hopelessness, while Tomas of the screenplay is aware of both of their existential turmoil and urges Jonas to recognize the coming of better days.

${ }^{16}$ The screenplay reads "MÄRTA. (slowly with pauses): If I could only lead him out of his emptiness, away from his lie-god. If we could dare show each other tenderness. If we could believe in the truth... If we could believe..." (104). Märta's reference to the "lie-god" complicates the interpretation of the scene as it is unclear if she is referring to Tomas's vision of his security-God and/or echo-God, or to illusion of God. However, this is of less importance than her recognition of, and resignation to, man's wretched existential state.

\section{FILMOGRAPHY}

Ingmar Bergman, dir. Sommarnattens leende/Smiles of a Summer Night. Perf. Ulla Jacobsson, Eva Dahlbeck, Harriet Andersson, and Gunnar Björnstrand. AB Svensk Filmindustri, 1955. Film.

--. Det sjunde inseglet/The Seventh Seal . Perf. Gunnar Björnstrand, Bengt Ekert, and Max von Sydow. AB Svensk Filmindustri, 1957. Film.

--. Såsom i en spegel/Through a Glass Darkly. Perf. Harriet Andersson, Gunnar Björnstrand, Lars Passgârd, and Max von Sydow. Janus Films, 1961. Film.

--. Nattvardgästerna/Winter Light. Perf. Gunnar Björnstrand, Ingrid Thulin, and Max von Sydow. AB Svensk Filmindustri, 1963. Film.

--. Tystnaden/The Silence. Perf. Gunnel Lindblom, Jörgen Lindström, and Ingrid Thulin. AB Svensk Filmindustri, 1963. Film. 


\section{REFERENCES}

Bergman, I. (1956). The Seventh Seal. London: Lorrimer Publishing Ltd. Print.

-- A Film Trilogy: Through a Glass Darkly, The Communicants (Winter Light), The Silence. Trans. Paul Britten Austin. London: Calder and Boyars Ltd., 1967. Print.

--. The Magic Lanter: An Autobiography. Trans. Joan Tate. New York: Viking Penguin Inc., 1988. Print.

-. Images: My Life in Film. Trans. Marianne Ruuth. London: Bloomsbury, 1994. Print.

Björkman, Stig, Torsten Manns, and Jonas Sima. Bergman on Bergman. Trans. Paul Britten Austin. London: Secker \& Warburg Ltd., 1973. Print.

Cohen, Hubert I. Ingmar Bergman: The Art of Confession. New York: Twayne Publishers, 1993. Print.

Cowie, Peter. Ingmar Bergman: A Critical Biography. New York: Scribers, 1982. Print.

--. "The Seventh Seal .” The Criterion Collection. The Criterion Collection, 12 Oct. 1987. Web. 13 July 2012.

Kalin, J. (2003). The films of ingmar bergman. Cambridge: Cambridge UP, 2003. Print.

Kartal, E. (2012) Seeking God in Early Bergman: The Cases of The Seventh Seal and Winter Light." CINEJ Cinema Journal 1(2): 80-85. Web. 25 June 2012.

Sjöman, Vilgot. "From L136: A Diary of Ingmar Bergman's Winter Light." Trans. Kaaren Grimstad. Cinema Journal 13.2 (Spring 1974): 34-40. Web. JSTOR. 10 July 2012.

-. L136: Diary with Ingmar Bergman. Trans. Alan Blair. Ann Arbor: Karoma Publishers, 1978. Print.

--. "Excerpts from L136: Diary with Ingmar Bergman.” Ingmar Bergman Interviews. Trans. Alan Blair. Raphael Shargel, ed. Jackson: UP of Mississippi, 2007. 21-34. Print.

Stubbs, J. C. (1975) The Seventh Seal. Journal of Aesthetic Education 9(2):62-76. JSTOR. 10 July 2012.

“Winter Light.” Ingmar Bergman Foundation. 22 May 2012. Web. 11 July 2012.

Young, C. (1969) The Seventh Seal. Film Quarterly 12(3), 42-44. Web. JSTOR. 10 July 2012. 